Article

\title{
Anti-Inflammatory Effects of Formononetin 7-O-phosphate, a Novel Biorenovation Product, on LPS-Stimulated RAW 264.7 Macrophage Cells
}

\author{
Min-Seon Kim ${ }^{1}$, Jin-Soo Park ${ }^{2} \oplus$, You Chul Chung ${ }^{3}$, Sungchan Jang ${ }^{1}$, Chang-Gu Hyun ${ }^{3}$ and \\ Seung-Young Kim ${ }^{1, *}$ \\ 1 Department of Pharmaceutical Engineering \& Biotechnology, Sunmoon University, Chungnam 31460, Korea; \\ nari7040@gmail.com (M.-S.K.); biochem1004@gmail.com (S.J.) \\ 2 Natural Product Informatics Research Center, KIST Gangneung Institute of Natural Products, Korea Institute \\ of Science and Technology (KIST), 679, Saimdang-ro 25451, Korea; jinsoopark@kist.re.kr \\ 3 Department of Chemistry and Cosmetics, Jeju National University, Jeju 63243, Korea; \\ jyc8385@hanmail.net (Y.C.C.); cghyun@jejunu.ac.kr (C.-G.H.) \\ * Correspondence: sykim01@sunmoon.ac.kr; Tel.: +82-41-530-2390
}

Received: 17 October 2019; Accepted: 29 October 2019; Published: 30 October 2019

check for updates

\begin{abstract}
Biorenovation is a microbial enzyme-catalyzed structural modification of organic compounds with the potential benefits of reduced toxicity and improved biological properties relative to their precursor compounds. In this study, we synthesized a novel compound verified as formononetin 7-O-phosphate (FMP) from formononetin (FM) using microbial biotransformation. We further compared the anti-inflammatory properties of FMP to FM in lipopolysaccharide (LPS)-treated RAW264.7 macrophage cells. We observed that cell viabilities and inhibitory effects on LPS-induced nitric oxide (NO) production were greater in FMP-treated RAW 264.7 cells than in their FM-treated counterparts. In addition, FMP treatment suppressed the production of proinflammatory cytokines such as prostaglandin- $\mathrm{E}_{2}\left(\mathrm{PGE}_{2}\right)$, interleukin-6 (IL-6), and interleukin-1 $\beta$ (IL-1 $\beta$ ) in a dose-dependent manner and concomitantly decreased the mRNA expression of inducible NO synthase (iNOS) and cyclooxygenase-2 (COX-2). We also found that FMP exerted its anti-inflammatory effects through the downregulation of the extracellular signal-regulated kinase (ERK), c-Jun $N$-terminal kinase (JNK), and nuclear factor kappa B (NF-kB) signaling pathways. In conclusion, we generated a novel anti-inflammatory compound using biorenovation and demonstrated its efficacy in cell-based in vitro assays.
\end{abstract}

Keywords: biorenovation; formononetin 7-O-phosphate; anti-inflammatory; MAPK pathway; NF-kB pathway

\section{Introduction}

Inflammation is an early host immune reaction mediated by cytokines secreted from immune cells [1,2]. This response plays a key role in the development of various human chronic diseases, including bronchitis, cancer, diabetes, and rheumatoid arthritis [3]. Macrophages, which play a major role in the immune response, perform an important role in the initiation, maintenance, and resolution of inflammation [4]. Macrophages are activated by stimuli such as interferon- $\gamma$ (IFN- $\gamma$ ), bacterial lipopolysaccharides (LPS), proinflammatory cytokines (including tumor necrosis factor- $\alpha$ (TNF- $\alpha$ ), interleukin-6 (IL-6), and interleukin-1 $\beta$ (IL-1 $\beta)$ ), extracellular matrix proteins, and other chemical mediators [5]. Upon activation by these stimuli, macrophages produce numerous proinflammatory mediators, such as nitric oxide (NO), prostaglandin-E2 (PGE2), and TNF- $\alpha$, to promote inflammatory responses [6]. NO is a key signaling molecule in a number of biological processes, including vasodilation, 
neurotransmission, the inhibition of platelet aggregation, and the immune response. NO is generated through the oxidation of L-arginine, which is catalyzed by nitric oxide synthase (NOS) enzymes [7-9]. The overproduction of NO by inducible nitric oxide synthase (iNOS) forms reactive nitrogen species, resulting in cell death in surrounding tissues and the disruption of tissue homeostasis [10,11].

$\mathrm{PGE}_{2}$, another mediator of inflammation, is known to induce cancer by activating angiogenesis [12-14]. Cyclooxygenase (COX) is a key enzyme in the biosynthetic pathway of $\mathrm{PGE}_{2}$, with two isozymes, COX-1 and COX-2. COX-2 can be upregulated by various inflammatory cytokines. In contrast, COX-1 is constitutively expressed in most cells at an essentially constant level and plays an important role in housekeeping functions [15-17].

The LPS stimulation of macrophages activates several intracellular signaling pathways that include the IкB kinase (IKK)-nuclear factor kappa B (NF-kB) pathway and three classical mitogen-activated protein kinase (MAPK) pathways: extracellular signal-regulated kinase (ERK), c-Jun N-terminal kinase (JNK), and p38 [18-20]. The activation of NF- $\mathrm{KB}$, when induced by LPS, involves the phosphorylation of IKK, leading to the subsequent ubiquitination and degradation of $I \kappa B \alpha$ and the translocation of NF- $\mathrm{KB}$ into the nucleus. The MAPK pathways modulate inflammatory gene transcription through the phosphorylation of the ERK, JNK, and p38 proteins [21,22]. The activation of these signaling pathways in turn activates a variety of transcription factors that control the expression of genes involved in inflammation, including iNOS and COX-2 [23]. Accordingly, MAPKs and NF- $\mathrm{kB}$ are important targets for anti-inflammatory molecules, and many putative anti-inflammatory therapies are based on the inhibition of their activity.

Flavonoids are a broad class of low-molecular-weight secondary plant phenolic compounds characterized by a flavan nucleus [24]. Widely distributed in the leaves, seeds, bark, and flowers of plants, over 4000 flavonoids have been identified to date [25]. Among them, formononetin (FM, biochanin B) is an O-methylated isoflavone phytoestrogen from the root of Astragalus membranaceus [26] that is reported to have antibreast cancer [27], estrogenic [28], and antihypertensive [29] effects.

To study the development of new anti-inflammatory drug sources, FM was converted using a biorenovation technique described previously [30,31]. Biorenovation is a method of producing various derivatives from precursors using the biocatalytic reactions of microorganisms. In this study, Bacillus amyloliquefaciens KCTC 13,588 was used as a biocatalyst to produce FM derivatives. The aim of this study was to investigate the anti-inflammatory activity of biorenovated FM and to establish its functional properties by examining the expression levels of various factors.

\section{Results}

\subsection{Analysis and Identification of the Biorenovation Product of Formononetin}

In this study, Bacillus amyloliquefaciens KCTC 13,588 was used for the production of biorenovation derivatives of FM. The reaction products were detected by HPLC analysis. Three peaks distinct from those of the standard compound were found in the culture supernatant (Figure 1A). Preparative HPLC was used to purify the compound (compound 1) responsible for the largest of these peaks. Electrospray ionization-mass spectrometry (ESI/MS) analysis was then performed to determine if the compound was a derivative of FM. The mass spectrum of compound 1 showed a representative peak at $m / z 269$ corresponding to the characteristic fragmentation of FM. This result suggested that compound 1 was a derivative of FM. The molecular formula $\mathrm{C}_{16} \mathrm{H}_{13} \mathrm{O}_{7} \mathrm{P}$, which was determined by high-resolution ESI/MS (HR-ESI/MS), suggested that this compound was a phosphorylated form of FM. For structural identification, compound 1 was analyzed by $1 \mathrm{D}$ and $2 \mathrm{D}$ NMR, including ${ }^{1} \mathrm{H} \mathrm{NMR},{ }^{13} \mathrm{C}$ NMR, HSQC, and HMBC spectroscopy. Proton signals (7.29 ppm for H-6 and 7.41 ppm for H-8) of compound 1 were downfield-shifted compared to those of FM (6.94 ppm for H-6 and $6.86 \mathrm{ppm}$ for H-8), suggesting the presence of a phosphate group at 7-OH. Furthermore, the phosphorylation at 7-OH was confirmed by split carbon signals of C-6 and C-8 due to C-P coupling $\left(J_{C}-P=5.5 \mathrm{~Hz}\right)$. To our knowledge, this structure, formononetin 7-O-phosphate (FMP), has not been reported to date (Figure 1B). 
(A)

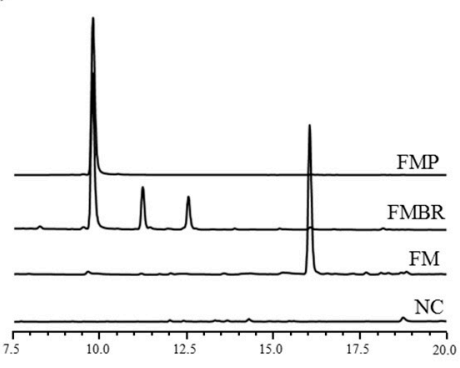

(B)

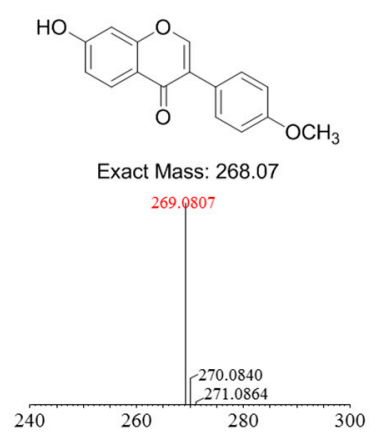

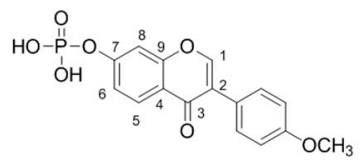

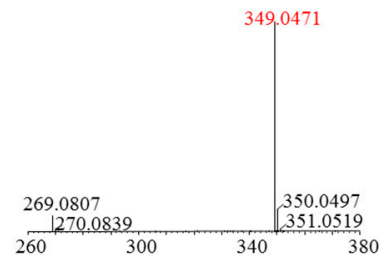

Figure 1. (A) HPLC analysis of formononetin (FM), a formononetin biorenovation product (FMBR), a biorenovation negative control (NC), and formononetin 7-O-phosphate (FMP); (B) structure and mass analysis of FM and FMP.

\subsection{NMR Results}

Formononetin 7-O-phosphate (FMP, 1): ${ }^{1} \mathrm{H}$ NMR (DMSO-d $\left.6,500 \mathrm{MHz}\right): \delta 8.43(1 \mathrm{H}, \mathrm{s}, \mathrm{H}-2), 8.08$ $(1 \mathrm{H}, \mathrm{d}, J=8.8 \mathrm{~Hz}, \mathrm{H}-5), 7.51\left(2 \mathrm{H}, \mathrm{m}, \mathrm{H}-2^{\prime}, \mathrm{H}-6^{\prime}\right), 7.41(1 \mathrm{H}, \mathrm{d}, J=2.2 \mathrm{~Hz}, \mathrm{H}-8), 7.29(1 \mathrm{H}, \mathrm{dd}, J=8.8$, $2.2 \mathrm{~Hz}, \mathrm{H}-6), 6.99$ (2H, m, H-3', H-5'), $3.78\left(3 \mathrm{H}, \mathrm{s}, \mathrm{OCH}_{3}\right) .{ }^{13} \mathrm{C}$ NMR (DMSO-d 6 , $125 \mathrm{MHz}$ ): $\delta 175.14$ (C-4), 159.46 (C-4'), 156.86 (C-8a), 156.75 (C-7), 154.35 (C-2), 130.53 (C-2' , C-6' ), 127.49 (C-5), 124.32 (C-3), $123.85\left(\mathrm{C}-1^{\prime}\right), 120.10(\mathrm{C}-4 \mathrm{a}), 118.84(\mathrm{C}-6, \mathrm{~d}, J=5.5 \mathrm{~Hz}), 114.06\left(\mathrm{C}-3^{\prime}, \mathrm{C}^{\prime} 5^{\prime}\right), 108.44(\mathrm{C}-8, \mathrm{~d}, J=5.0 \mathrm{~Hz})$, $55.59\left(\mathrm{OCH}_{3}\right)$. HR-ESI/MS: $\mathrm{m} / z$ [M + H] 349.0471, calcd 349.0477 (see Supplementary Materials).

\subsection{Cytotoxic Effects of Compounds on RAW 264.7 Cells}

RAW 264.7 macrophage cells were treated with varying concentrations of FM or FMP (12.5, $25,50$, and $100 \mu \mathrm{M})$ with or without LPS $(1 \mu \mathrm{g} / \mathrm{mL})$ for $24 \mathrm{~h}$. An MTT (3-(4,5-dimethylthiazol2-yl)-2,5-diphenyltetrazolium bromide) assay showed that cell viability decreased by $42 \%, 48 \%$, and $50 \%$ in cells treated with 25,50 , and $100 \mu \mathrm{M}$ FM, respectively, but that FMP was nontoxic to RAW 264.7 cells at these concentrations (Figure 2A). These results indicate that the changes made through biorenovation contributed to the improvement of cell viability.

(A)

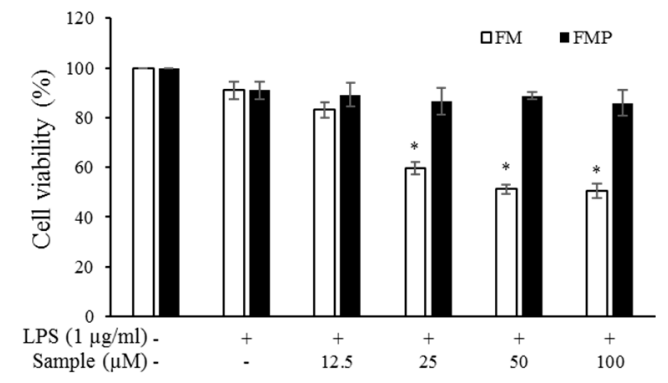

(B)

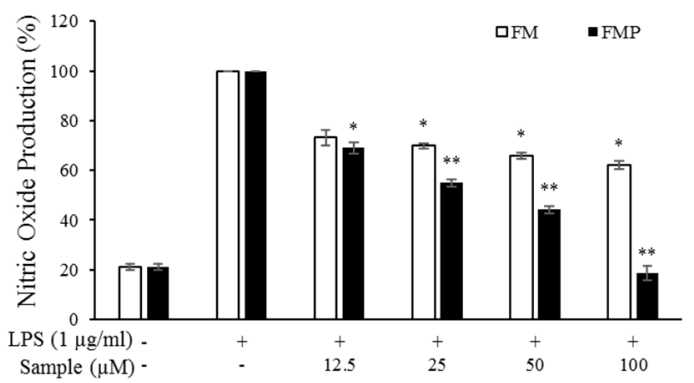

Figure 2. Effects on cell viability and nitric oxide production by FM and FMP in lipopolysaccharide (LPS)-stimulated RAW 264.7 cells. (A) Cell viability was assessed in cells stimulated with LPS (1 $\mu \mathrm{g} / \mathrm{mL})$ in the presence of FM or FMP for $24 \mathrm{~h}$; (B) nitric oxide production was determined using the Griess reagent method. The data represent the mean $\pm \mathrm{SD}$ of triplicate experiments. ${ }^{*} p<0.05,{ }^{* *} p<0.01$ versus LPS alone.

\subsection{Production of $N O$ and $P G E_{2}$}

The effects of FM and FMP on NO production were measured in cells treated with various concentrations of FM and FMP for $24 \mathrm{~h}$. LPS $(1 \mu \mathrm{g} / \mathrm{mL})$ was used as a negative control. As shown in Figure 2B, FM treatment decreased NO production compared to the group treated with LPS alone. However, this result was accompanied by notable decreases in cell viability (Figure 2A). FMP, however, 
reduced NO production in a dose-dependent manner without signs of cytotoxicity. Overall, FMP displayed a greater inhibition of NO production than FM did. Thus, FMP treatment was chosen to measure $\mathrm{PGE}_{2}$ concentrations. As a result, $\mathrm{PGE}_{2}$ production decreased $30 \%, 50 \%, 60 \%$, and $90 \%$ in cells treated with 12.5, 25, 50, and $100 \mu \mathrm{M}$ FMP, respectively (Figure 3A).

(A)

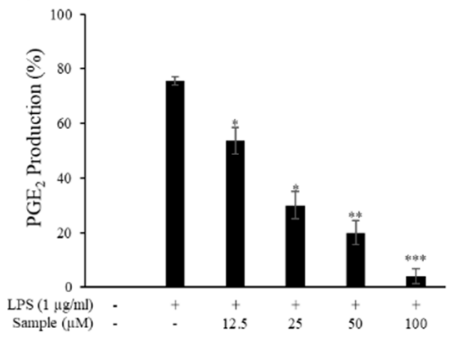

(B)

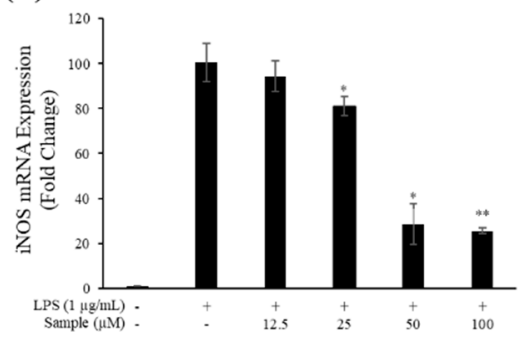

(C)

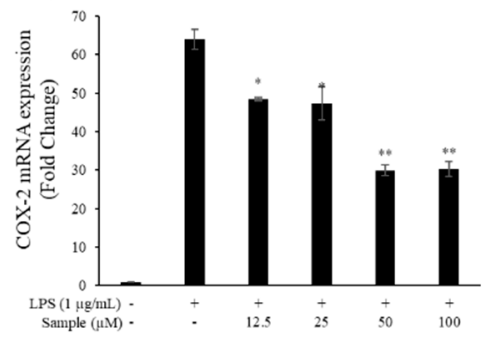

Figure 3. Effects of FMP on prostaglandin- $\mathrm{E}_{2}\left(\mathrm{PGE}_{2}\right)$ production and mRNA levels of inducible-nitric oxide synthase (iNOS) and cyclooxygenase-2 (COX-2) in LPS-stimulated RAW 264.7 cells. (A) The production of PGE $_{2}$ was assayed in the culture medium of cells stimulated with LPS $(1 \mu \mathrm{g} / \mathrm{mL})$ for $24 \mathrm{~h}$ in the presence of FMP $(12.5,25,50$, and $100 \mu \mathrm{M})$ by ELISA; (B,C) mRNA levels of iNOS and COX-2 were determined by qRT-PCR. The data represent the mean \pm SD of triplicate experiments. ${ }^{*} p<0.05$, ${ }^{* *} p<0.01,{ }^{* * *} p<0.005$ versus LPS alone.

\section{5. $m R N A$ Levels of $i N O S$ and COX-2}

To determine whether the inhibitory effect of FMP on $\mathrm{NO}$ and $\mathrm{PGE}_{2}$ production was due to the suppression of iNOS and COX-2 expression, the mRNA expression of these enzymes was measured. FMP significantly reduced the expression of iNOS at concentrations ranging from 25 to $100 \mu \mathrm{M}$ (Figure 3B) and the expression of COX-2 at concentrations ranging from 12.5 to $100 \mu \mathrm{M}$ (Figure 3C) relative to the group treated with LPS alone. These results indicate that the reduction of iNOS and COX-2 mRNA levels was key to the decreased expression of $\mathrm{NO}$ and $\mathrm{PGE}_{2}$.

\subsection{Production of Proinflammatory Cytokines}

An ELISA was performed to assess the effects of FMP on the production of proinflammatory cytokines (TNF- $\alpha$, IL-1 $\beta$, and IL-6) in RAW 264.7 cells. As shown in Figure 4B,C, FMP treatment at the indicated concentrations reduced IL- $1 \beta$ and IL- 6 expression in a dose-dependent manner. Notably, treatment with FMP at $100 \mu \mathrm{M}$ inhibited IL- $1 \beta$ and IL- 6 expression by $50 \%$ and $70 \%$, respectively, compared to the group treated with LPS alone. However, treatment with FMP did not affect TNF- $\alpha$ expression, indicating that TNF- $\alpha$ may not be involved in mediating the anti-inflammatory effects of FMP (Figure 4A).

(A)

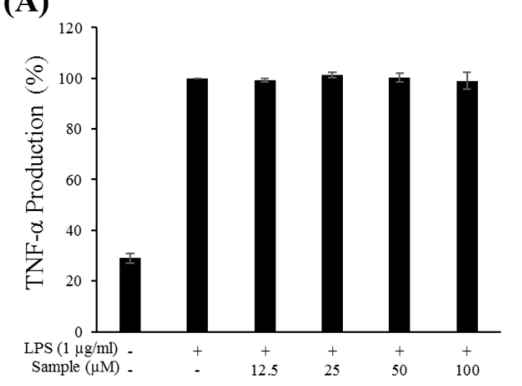

(B)

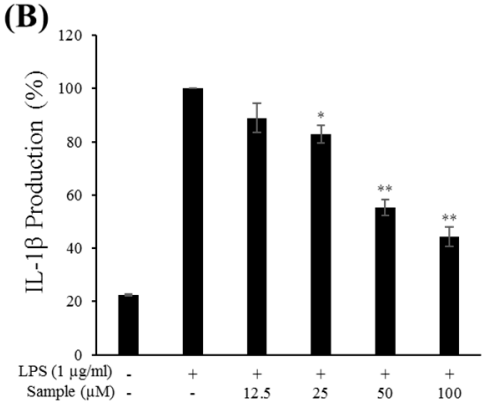

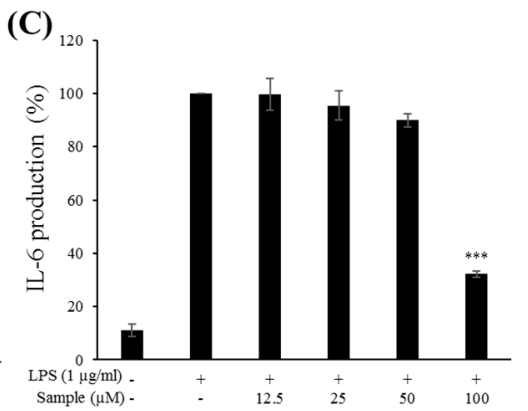

Figure 4. Effect of FMP on (A) tumor necrosis factor- $\alpha$ (TNF- $\alpha)$, (B) interleukin-1 $\beta$ (IL-1 $\beta$ ), and (C) interleukin-6 (IL-6) production in LPS-stimulated RAW 264.7 cells. Cells were stimulated with $1 \mu \mathrm{g} / \mathrm{mL}$ of LPS only or with LPS plus varying concentrations $(12.5,25,50$, and $100 \mu \mathrm{g} / \mathrm{mL}$ ) of FMP for $24 \mathrm{~h}$. Protein production was determined through an ELISA. The data represent the mean \pm SD of triplicate experiments. ${ }^{*} p<0.05,{ }^{* *} p<0.01,{ }^{* * *} p<0.005$ versus LPS alone. 


\subsection{Expression of MAPK and NF- $\kappa B$ Pathways}

To study the effects of FMP on inflammatory signaling pathways in LPS-stimulated RAW 264.7 macrophage cells, MAPK and NF- $\mathrm{KB}$ signaling pathway proteins were measured. As shown in Figure 5C, the phosphorylation of JNK was significantly diminished by FMP. Both ERK and p38 also exhibited slightly decreased phosphorylation at the highest concentration of FMP (Figure 5A,B). These results also suggest that FMP treatment may affect the NF- $\mathrm{kB}$ signaling pathway by increasing the expression level of IkB- $\alpha$ and decreasing the phosphorylation level of NF- $\kappa B$ (Figure 5D,E). These results indicate that FMP inhibited the expression of proinflammatory cytokines and inflammatory mediators through the MAPK and NF-kB signaling pathways.

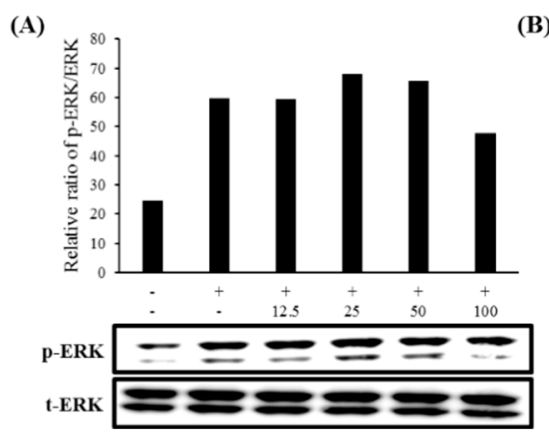

(D)
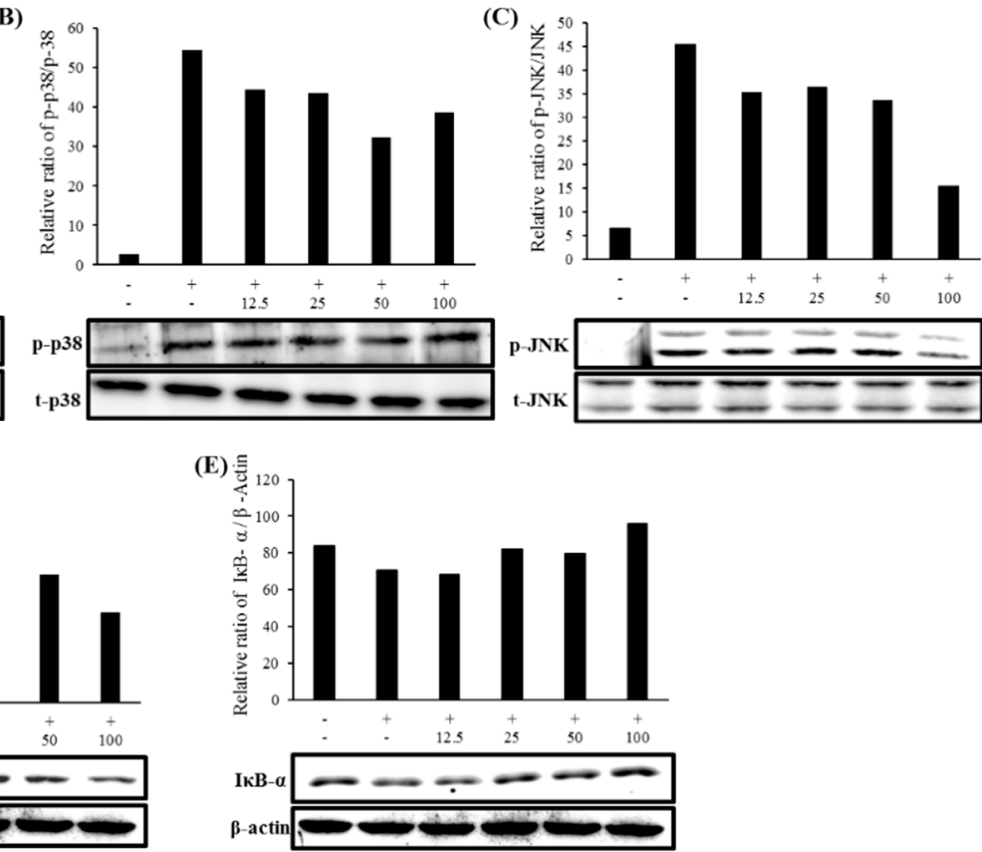

Figure 5. Effect of FMP on the protein levels of (A) extracellular signal-regulated kinase (ERK), (B) p38, (C) c-Jun N-terminal kinase (JNK), (D) nuclear factor kappa B (NF-kB), and (E) IkB kinase in LPS-stimulated RAW 264.7 cells. Cells $\left(1.5 \times 10^{5}\right.$ cell $\left./ \mathrm{mL}\right)$ were stimulated with LPS $(1 \mu \mathrm{g} / \mathrm{mL})$ in the presence of FMP $(12.5,25,50$, and $100 \mu \mathrm{M})$ for $30 \mathrm{~min}$. Whole-cell lysates $(30 \mu \mathrm{g})$ were prepared, the protein level was subjected to $10 \%$ SDS-PAGE, and the expression of MAPK, NF- $\mathrm{kB}$ and $\beta$-actin was determined by western blotting.

\section{Discussion}

To develop a novel anti-inflammatory agent, we employed a biorenovation process using FM as a substrate. We identified this new compound as FMP using MS and NMR.

Macrophages are known to play a critical role in acute and chronic inflammatory responses through the production of proinflammatory factors such as $\mathrm{NO}, \mathrm{PGE}_{2}$, and cytokines, including TNF- $\alpha$, IL-1 $\beta$, and IL-6. Exposure to high levels of NO can induce an innate immune response and cause tissue damage or cell injury [32].

In this study, FMP was shown to exhibit lower cytotoxicity in macrophages relative to FM, indicating that cell viability was improved by the biorenovation reaction. Therefore, further research was conducted examining the anti-inflammatory activity of FMP. Treatment with FMP reduced the secretion of $\mathrm{NO}$ and $\mathrm{PGE}_{2}$ and the mRNA expression of their respective enzymes, iNOS and COX-2, in a dose-dependent manner. These results suggest that the inhibition of $\mathrm{NO}$ and $\mathrm{PGE}_{2}$ production seen in cells was due to the downregulation of mRNA expressions of iNOS and COX-2.

The proinflammatory cytokines TNF- $\alpha$, IL- 6 , and IL- $1 \beta$ cause tissue damage and play a key role in mediating various inflammatory diseases [6]. FMP decreased the secretion of IL- 6 and IL-1 $\beta$ but 
had no effect on TNF- $\alpha$ production. Therefore, we suggest that FMP exerted its anti-inflammatory effects through the reduced production of IL- 6 and IL-1 $\beta$.

We also investigated whether or not the anti-inflammatory effects of FMP were mediated through the MAPK and NF- $\mathrm{kB}$ signaling pathways via the effects of FMP on the LPS-induced phosphorylation of upstream kinases. FMP treatment lowered the upregulated expression levels of phosphorylated ERK, JNK, p38, NF-kB, and IKB seen in the treatment group to the level of the untreated control group. Thus, the decreased production of iNOS, COX-2, and proinflammatory cytokines was concluded to be due to the modulation of the MAPK and NF-kB signaling pathways.

Additionally, our previous research $[30,31]$ indicated that the two additional compounds observed in the HPLC chromatogram of FMBR (Figure 1A) were ononin (formononetin 7-O-glucoside, $\mathrm{C}_{22} \mathrm{H}_{22} \mathrm{O}_{9}$ ) and succinyl-ononin $\left(\mathrm{C}_{26} \mathrm{H}_{26} \mathrm{O}_{12}\right)$. The macrophage-mediated anti-inflammatory effects of ononin were studied by L Dong et al. [33], with results similar to those of FMP in this study. However, FMP inhibited the production of $\mathrm{PGE}_{2}$ more effectively than ononin, suggesting that the compounds act by different mechanisms. Further investigation into the anti-inflammatory activity of succinyl-ononin is needed before its effects can be compared to those of FMP.

With interest in research on the health-promoting effects of flavonoid compounds growing [34], we have shown here that a biorenovation product can exhibit stronger anti-inflammatory properties than its substrate. As expected, the anti-inflammatory activity of FMP was regulated through the MAPK and NF-kB pathways, and its activity was higher than FM. Our results suggest that formononetin 7-O-phosphate, a novel compound synthesized by biorenovation, may be a promising candidate in the development of new anti-inflammatory drugs.

\section{Materials and Methods}

\subsection{Reagents and Bacterial Strain Used in Biorenovation}

Formononetin was purchased from Selleck Chemicals (Houston, TX, USA). Nutrient medium components were purchased from Difco (Baltimore, MD, USA). The microorganism B. amyloliquefaciens KCTC 13,588 was purchased from KCTC (Korean Collection for Type Cultures, Seoul, Republic of Korea). All reagents for RAW 264.7 cell culture were purchased from Bio-rad (Hercules, CA, USA) or Cell Signaling Technology (Danvers, MA, USA).

\subsection{Biorenovation of Formononetin}

For use as an inoculum, B. amyloliquefaciens KCTC 13,588 was cultured by placing colonies from agar plates in $4 \mathrm{~mL}$ of nutrient broth ( $3 \mathrm{~g} / \mathrm{L}$ of beef extract (ThermoFisher, Waltham, MA, USA) and peptone (ThermoFisher) $5 \mathrm{~g} / \mathrm{L}$ ) in a culturing tube, and $0.2 \%$ of the inoculum of B. amyloliquefaciens KCTC 13,588 was added to a $500-\mathrm{mL}$ flask containing $100 \mathrm{~mL}$ of nutrient medium and cultured at $37^{\circ} \mathrm{C}$ and $200 \mathrm{rpm}$ for $18 \mathrm{~h}$. Culture broth was centrifuged at $5000 \mathrm{rpm}$ for $15 \mathrm{~min}$, and the supernatant was discarded. The remaining cells were washed with phosphate glycerin buffer (PG buffer) containing $2 \% v / v$ glycerin in $50 \mathrm{mM}$ of sodium phosphate at $\mathrm{pH} 7.2$. After adding $5 \mathrm{~mL}$ of PG buffer, cells were resuspended through vortexing and centrifuging at $5000 \mathrm{rpm}$ for $5 \mathrm{~min}$. After discarding the supernatant, the washing was repeated. Formononetin was added to a final concentration of $4 \mathrm{mg} / \mathrm{mL}$. Media were further incubated at $30^{\circ} \mathrm{C}$ and $200 \mathrm{rpm}$ for $48 \mathrm{~h}$. After centrifugation at $5000 \mathrm{rpm}$ for $10 \mathrm{~min}$, the supernatant was concentrated using an evaporator.

\subsection{HPLC Analysis and Purification of Formononetin Biorenovation Product}

For HPLC analysis, a Shimadzu SpectroMonitor 3200 digital UV-Vis detector equipped with a Shim-pack GIS 0.5-mm ODS C18 column $(250 \times 4.6 \mathrm{~mm}$ id) was used (Shimadzu, Kyoto, Japan). The mobile phase consisted of water containing $0.1 \% v / v$ trifluoroacetic acid (TFA) (solvent A) and acetonitrile (solvent B). A gradient method was used with a flow rate of $1 \mathrm{~mL} / \mathrm{min}$ of solvent $B$, which 
was increased from $10 \%$ to $100 \%$ over $30 \mathrm{~min}$, maintained for $5 \mathrm{~min}$, and then reduced to $10 \%$ over $3 \mathrm{~min}$ and maintained for $5 \mathrm{~min}$.

\subsection{LCMS and NMR Analysis of Formononetin Biorenovation Product}

High-resolution quadrupole-time-of-flight electrospray ionization-mass spectrometry (HR-QTOF ESI/MS) analysis was performed in positive ion mode using an ACQUITY UPLC system coupled with a SYNAPT G2-Si column (Waters Corporation, Milford, MA, USA). NMR spectra were measured using a VNMRS 500 NMR spectrometer (Agilent Technology, Santa Clara, CA, USA), and residual solvent peaks (DMSO- $\mathrm{d}_{6}=\delta_{\mathrm{H}}$ 2.50) of deuterated NMR solvents (Sigma-Aldrich, St. Louis, MA, USA) were used as reference peaks.

\subsection{Cell Culture and Viability Assay}

RAW 264.7 macrophage cells were acquired from the Korean Cell Line Bank (KCLB, Seoul, Korea). Cells were cultured in DMEM supplemented with 10\% heat-inactivated FBS with 1\% penicillin and streptomycin and placed in a humidified incubator in a $5 \% \mathrm{CO}_{2}$ atmosphere at $37{ }^{\circ} \mathrm{C}$. At $80 \%-90 \%$ confluence, cells were plated at a density of $1.5 \times 10^{5}$ cells/well in 24 -well plates and incubated for $24 \mathrm{~h}$. Cells were treated with varying concentrations of either FM or FMP $(12.5,25,50$, and $100 \mu \mathrm{M})$ with or without LPS $(1 \mu \mathrm{g} / \mathrm{mL})$ for $24 \mathrm{~h}$. Cell viability was measured using a 3-(4,5-dimethylthiazol-2-yl)-2,5-diphenyltetrazolium bromide (MTT) assay [35]. MTT reagent (Sigma-Aldrich, St. Louis, MA, USA) was added at a concentration of $5 \mathrm{mg} / \mathrm{mL}$ to each well, and cells were then incubated for $3 \mathrm{~h}$. Subsequently, formazan crystals were dissolved in DMSO, and absorbance at $570 \mathrm{~nm}$ was read using a microplate reader (Spectrophotometer, ThermoFisher).

\subsection{Determination of $\mathrm{NO}$ and $P G E_{2}$ Production}

RAW 264.7 cells were plated at a density of $1.5 \times 10^{5}$ cells/well in 24-well plates and incubated for $24 \mathrm{~h}$. Cells were treated with varying concentrations of either FM or FMP $(12.5,25,50$, and $100 \mu \mathrm{M})$ (then with or without LPS $(1 \mu \mathrm{g} / \mathrm{mL}))$ for $24 \mathrm{~h}$. Cell culture supernatant $(100 \mu \mathrm{L})$ was mixed with Griess reagent (Sigma-Aldrich, St. Louis, MA, USA) $(100 \mu \mathrm{L})$, and absorbance was determined at $540 \mathrm{~nm}$ to measure NO production. The concentration of $\mathrm{PGE}_{2}$ in the culture supernatant of cells treated with FMP 12.5, 25, 50, and $100 \mu \mathrm{M}$ was detected using a PGE 2 ELISA Kit (Mouse PGE 2 , R\&D Systems, MN, USA).

\subsection{Determination of TNF- $\alpha, I L-1 \beta$, and IL-6 Production}

RAW 264.7 cells were plated at a density of $1.5 \times 10^{5}$ cells/well in 24 -well plates and incubated for $24 \mathrm{~h}$. Cells were treated with varying concentrations of FMP $(12.5,25,50$, and $100 \mu \mathrm{M})($ then with or without LPS $(1 \mu \mathrm{g} / \mathrm{mL}))$ for $24 \mathrm{~h}$. The concentrations of proinflammatory cytokines (TNF- $\alpha$, IL-1 $\beta$, and IL-6) in culture supernatant were determined using ELISA kits (Mouse TNF alpha ELISA Kit, Invitrogen, Carlsbad, CA, USA; Mouse IL-6 ELISA Kit, BD, Franklin Lakes, NJ, USA; Mouse IL-1ß/IL-1F2, R\&D Systems, Minneapolis, MN, USA).

\subsection{Quantitative Reverse-Transcription Polymerase Chain Reaction ( $q R T-P C R)$ Analysis}

The total RNA obtained from RAW264.7 cells was isolated using an RNA extraction kit (RNeasy Mini Kit, QIAGEN, Hilden, Germany). Total RNA (1 $\mu \mathrm{g}$ ) was reverse-transcribed using a cDNA synthesis kit (PrimeScript 1st strand cDNA Synthesis Kit, TaKaRa, Kyoto, Japan), and qRT-PCR was performed using an SYBR Mixture (TB Green Premix Ex Taq II, TaKaRa, Kyoto, Japan). The primers used were as follows: iNOS-(F)AATGGCAACATCAGGTCGGCCATCACT; iNOS-(R) GCTGTGGTCACAGAAGTCTCGAACTC; COX-2-(F)GGAGAGACTATCAAGATAGT; COX-2-(R)ATGGTCAGTAGACTTTTACA; GAPDH(Glyceraldehyde 3-phosphate dehydrogenase)(R)GGTTTCTCCAGGCGGCA; and GAPDH-(F)GGCATGGCCTTCCGTGT. 


\subsection{Western Blot Analysis}

The total protein was extracted from the cells using RIPA buffer (Bio-red, Hercules, CA, USA) and measured with a Bradford assay kit (Pierce BCA Protein Assay Kit, Thermo Scientific, Waltham, MA, USA). Then, $20 \mu \mathrm{g}$ of proteins were separated by 10\% SDS-PAGE gel and transferred onto polyvinylidene difluoride (PVDF) membranes (Bio-red) at $250 \mathrm{~V}$ and for $1 \mathrm{~h}$. Membranes were blocked with 5\% skim milk at $1 \mathrm{~h}$ and incubated with primary Phospho-p44/42 MAPK (Erk1/2)(Thr202/Tyr204) Antibody (1:1000), Phospho-p38 MAP Kinase (Thr180/Tyr182) Antibody (1:500), Phospho-SAPK/JNK (Thr183/Tyr185) Antibody (1:500), p44/42 MAPK (Erk1/2) antibody (1:1000), p38 MAPK Antibody (1:500), SAPK/JNK Antibody (1:500), Phospho-NF-kB p65 (Ser536)(93H1) Rabbit mAb (1:500), and IkB $\alpha$ (L35A5) Mouse mAb Amino-Terminal Antigen (1:500) (Cell Signaling) at $4{ }^{\circ} \mathrm{C}$ overnight, followed by incubation with secondary antibody (1:10,000) (HRP Anti-Rabbit IgG (H\&L), Rockland Immunochemicals, Inc., USA) at $25^{\circ} \mathrm{C}$ for $1 \mathrm{~h}$. Proteins were detected using an ECL kit (Bio-red, Hercules, California, USA) and measured using an Image reader (LAS-4000, FUJIFILM, Tokyo, Japan).

\subsection{Statistical Analysis}

Results are expressed in terms of mean \pm SD. The statistical significance of the differences was evaluated using Student's $t$-test for the data acquired.

Supplementary Materials: The following are available online, Figure S1: 1H NMR of formononetin 7-O-phosphate (FMP, 1), Figure S2: 13C NMR of formononetin 7-O-phosphate (FMP, 1), Figure S3: HSQC correlation of formononetin 7-O-phosphate (FMP, 1), Figure S4: HMBC correlation of formononetin 7-O-phosphate (FMP, 1), Figure S5: 1H NMR of formononetin 7-O-glucoside.

Author Contributions: Conceptualization, S.-Y.K.; data curation, M.-S.K. and J.-S.P.; formal analysis, M.-S.K., J.-S.P., and Y.C.C.; project administration, S.-Y.K.; supervision, C.-G.H. and S.-Y.K.; writing-original draft, M.-S.K., Y.C.C., and S.J.; writing-review and editing, S.J. and S.-Y.K.

Funding: The Research Foundation of Korea (NRF), which is funded by the Ministry of Science, ICT, and Future Planning (2017R1C1B5018228), funded Prof. Seung-Young Kim.

Conflicts of Interest: The authors declare no conflicts of interest.

\section{References}

1. Becker, S.; Mundandhara, S.; Devlin, R.B.; Madden, M. Regulation of cytokine production in human alveolar macrophages and airway epithelial cells in response to ambient air pollution particles: Further mechanistic studies. Toxicol. Appl. Pharm. 2005, 207, 269-275. [CrossRef] [PubMed]

2. Lopes, A.J.O.; Vasconcelos, C.C.; Pereira, F.A.N.; Silva, R.H.M.; Queiroz, P.F.D.S.; Fernandes, C.V.; Cartágenes, M.D.S.D.S. Anti-Inflammatory and Antinociceptive Activity of Pollen Extract Collected by Stingless Bee Melipona fasciculate. Int. J. Mol. Sci. 2019, 20, 4512. [CrossRef] [PubMed]

3. Tazawa, H.; Kawaguchi, T.; Kobayashi, T.; Kuramitsu, Y.; Wada, S.; Satomi, Y.; Kitagawa, T. Chronic inflammation-derived nitric oxide causes conversion of human colonic adenoma cells into adenocarcinoma cells. Exp. Cell Res. 2013, 319, 2835-2844. [CrossRef] [PubMed]

4. Koh, T.J.; DiPietro, L.A. Inflammation and wound healing: The role of the macrophage. Expert Rev. Mol. Med. 2011, 13. [CrossRef]

5. Fujiwara, N.; Kobayashi, K. Macrophages in inflammation. Inflamm. Allergy Drug Targets 2005, 4, $281-286$. [CrossRef]

6. Lee, A.K.; Sung, S.H.; Kim, Y.C.; Kim, S.G. Inhibition of lipopolysaccharide-inducible nitric oxide synthase, TNF- $\alpha$ and COX-2 expression by sauchinone effects on $\mathrm{I}-\kappa \mathrm{B} \alpha$ phosphorylation, C/EBP and AP-1 activation. Br. J. Pharmacol. 2003, 139, 11-20. [CrossRef]

7. Udompong, S.; Mankhong, S.; Jaratjaroonphong, J.; Srisook, K. Involvement of p38 MAPK and ATF-2 signaling pathway in anti-inflammatory effect of a novel compound bis [(5-methyl) 2-furyl](4-nitrophenyl) methane on lipopolysaccharide-stimulated macrophages. Int. Immunopharmacol. 2017, 50, 6-13. [CrossRef]

8. Lieb, K.; Engels, S.; Fiebich, B.L. Inhibition of LPS-induced iNOS and NO synthesis in primary rat microglial cells. Neurochem. Int. 2003, 42, 131-137. [CrossRef] 
9. Katsuyama, K.; Shichiri, M.; Marumo, F.; Hirata, Y. NO inhibits cytokine-induced iNOS expression and NF-кB activation by interfering with phosphorylation and degradation of IкB- $\alpha$. Arter. Thromb. Vasc. Biol. 1998, 18, 1796-1802. [CrossRef]

10. Kim, B.H.; Reddy, A.M.; Lee, K.H.; Chung, E.Y.; Cho, S.M.; Lee, H.; Kim, Y. Inhibitory mechanism of chroman compound on LPS-induced nitric oxide production and nuclear factor-kB activation. Biochem. Biophys. Res. Commun. 2004, 325, 223-228. [CrossRef]

11. Coleman, J.W. Nitric oxide in immunity and inflammation. Int. Immunopharmacol. 2001, 1, $1397-1406$. [CrossRef]

12. Masferrer, J.L.; Zweifel, B.S.; Manning, P.T.; Hauser, S.D.; Leahy, K.M.; Smith, W.G.; Seibert, K. Selective inhibition of inducible cyclooxygenase 2 in vivo is antiinflammatory and nonulcerogenic. Proc. Natl. Acad. Sci. USA 1994, 91, 3228-3232. [CrossRef] [PubMed]

13. MacMicking, J.; Xie, Q.W.; Nathan, C. Nitric oxide and macrophage function. Annu. Rev. Immunol. 1997, 15, 323-350. [CrossRef] [PubMed]

14. Guo, J.Y.; Huo, H.R.; Yang, Y.X.; Li, C.H.; Liu, H.B.; Zhao, B.S. 2-methoxycinnamaldehyde reduces IL-1beta-induced prostaglandin production in rat cerebral endothelial cells. Biol. Pharm. Bull. 2006, 29, 2214-2221. [CrossRef]

15. Lin, C.Y.; Wang, W.H.; Chen, S.H.; Chang, Y.W.; Hung, L.C.; Chen, C.Y.; Chen, Y.H. Lipopolysaccharideinduced nitric oxide, prostaglandin $\mathrm{E}_{2}$, and cytokine production of mouse and human macrophages are suppressed by pheophytin-b. Int. J. Mol. Sci. 2017, 18, 2637. [CrossRef]

16. Riese, J.; Hoff, T.; Nordhoff, A.; DeWitt, D.L.; Resch, K.; Kaever, V. Transient expression of prostaglandin endoperoxide synthase-2 during mouse macrophage activation. J. Leukoc. Biol. 1994, 55, 476-482. [CrossRef]

17. Shan, J.; Fu, J.; Zhao, Z.; Kong, X.; Huang, H.; Luo, L.; Yin, Z. Chlorogenic acid inhibits lipopolysaccharide-induced cyclooxygenase-2 expression in RAW264. 7 cells through suppressing NF- $\mathrm{KB}$ and JNK/AP-1 activation. Int. Immunopharmacol. 2009, 9, 1042-1048. [CrossRef]

18. Liew, C.Y.; Lam, K.W.; Kim, M.K.; Harith, H.H.; Tham, C.L.; Cheah, Y.K.; Israf, D.A. Effects of 3-(2-Hydroxyphenyl)-1-(5-methyl-furan-2-yl) propenone (HMP) upon signalling pathways of lipopolysaccharide-induced iNOS synthesis in RAW 264.7 cells. Int. Immunopharmacol. 2011, 11, 85-95. [CrossRef]

19. Kim, E.K.; Choi, E.J. Pathological roles of MAPK signaling pathways in human diseases. Biochim. Biophys. Acta 2010, 1802, 396-405. [CrossRef]

20. Huang, P.; Han, J.; Hui, L. MAPK signaling in inflammation-associated cancer development. Protein $\mathcal{E}$ Cell 2010, 1, 218-226.

21. Zhao, Y.; Liu, J.; Liu, C.; Zeng, X.; Li, X.; Zhao, J. Anti-inflammatory effects of p-coumaric acid in LPS-stimulated RAW264. 7 cells: Involvement of NF-кB and MAPKs pathways. J. Med. Chem. 2016, 6, 327-330.

22. Bi, W.Y.; Fu, B.D.; Shen, H.Q.; Wei, Q.; Zhang, C.; Song, Z.; Yi, P.F. Sulfated derivative of 20 (S)-ginsenoside Rh2 inhibits inflammatory cytokines through MAPKs and NF-kappa B pathways in LPS-induced RAW264. 7 macrophages. Inflammation 2012, 35, 1659-1668. [CrossRef] [PubMed]

23. Kleinert, H.; Art, J.; Pautz, A. Regulation of the expression of inducible nitric oxide synthase. Nitric Oxide 2010, 211-267. [CrossRef]

24. Zhishen, J.; Mengcheng, T.; Jianming, W. The determination of flavonoid contents in mulberry and their scavenging effects on superoxide radicals. Food Chem. 1999, 64, 555-559. [CrossRef]

25. Heim, K.E.; Tagliaferro, A.R.; Bobilya, D.J. Flavonoid antioxidants: Chemistry, metabolism and structure-activity relationships. J. Nutr. Biochem. 2002, 13, 572-584. [CrossRef]

26. Wang, Y.; Zhu, Y.; Gao, L.; Yin, H.; Xie, Z.; Wang, D.; Han, X. Formononetin attenuates IL-1 $\beta$-induced apoptosis and NF-kB activation in INS-1 cells. Molecules 2012, 17, 10052-10064. [CrossRef]

27. Chen, J.; Zeng, J.; Xin, M.; Huang, W.; Chen, X. Formononetin induces cell cycle arrest of human breast cancer cells via IGF1/PI3K/Akt pathways in vitro and in vivo. Trends Endocrinol. Metab. 2011, 43, 681-686. [CrossRef]

28. Ji, Z.N.; Zhao, W.Y.; Liao, G.R.; Choi, R.C.; Lo, C.K.; Dong, T.T.X.; Tsim, K.W.K. In vitro estrogenic activity of formononetin by two bioassay systems. Gynecol. Endocrinol. 2006, 22, 578-584. [CrossRef]

29. Tao, S.U.N.; Rui, L.I.U.; Cao, Y.X. Vasorelaxant and antihypertensive effects of formononetin through endothelium-dependent and-independent mechanisms. Acta Pharmacol. Sin. 2011, 32, 1009. 
30. Kim, K.M.; Park, J.S.; Choi, H.R.; Kim, M.S.; Seo, J.H.; Pandey, R.P.; Kim, S.Y. Biosynthesis of novel daidzein derivatives using Bacillus amyloliquefaciens whole cells. Biocatal Biotransformation. 2018, 36, 469-475. [CrossRef]

31. Choi, H.R.; Park, J.S.; Kim, K.M.; Kim, M.S.; Ko, K.W.; Hyun, C.G.; Kim, S.Y. Enhancing the antimicrobial effect of genistein by biotransformation in microbial system. Ind. Eng. Chem. 2018, 63, 255-261. [CrossRef]

32. Olefsky, J.M.; Glass, C.K. Macrophages, inflammation, and insulin resistance. Annu. Rev. Physiol. 2010, 72, 219-246. [CrossRef]

33. Dong, L.; Yin, L.; Zhang, Y.; Fu, X.; Lu, J. Anti-inflammatory effects of ononin on lipopolysaccharide-stimulated RAW 264.7 cells. Mol. Immunol. 2017, 83, 46-51. [CrossRef]

34. Marzocchella, L.; Fantini, M.; Benvenuto, M.; Masuelli, L.; Tresoldi, I.; Modesti, A.; Bei, R. Dietary flavonoids: Molecular mechanisms of action as anti-inflammatory agents. Recent Pat. Inflamm Allergy Drug Discov. 2011, 5, 200-220. [CrossRef]

35. Mosmann, T. Rapid colorimetric assay for cellular growth and survival: Application to proliferation and cytotoxicity assays. J. Immunol. Methods 1983, 65, 55-63. [CrossRef]

Sample Availability: Samples of the compounds are not available from the authors.

(C) 2019 by the authors. Licensee MDPI, Basel, Switzerland. This article is an open access article distributed under the terms and conditions of the Creative Commons Attribution (CC BY) license (http://creativecommons.org/licenses/by/4.0/). 